\title{
Engellilerin Afete Dirençliliği ve Van'da Yerel Örgütlenme
}

\author{
Oya AÇIKALIN RASHEM ${ }^{1}$ ve Fırat ASLANGIRi ${ }^{2 *}$
}

\section{Öz}

Türkiye'de son on yıldır afet yönetimi anlayışında kriz yönetiminden risk yönetimine doğru bir dönüşüm gerçekleşmektedir. Katılımcılığa dayanan bu yeni yaklaşım, afet öncesinde tehlikelerin kavranmasını, bunların yol açabileceği zararların hesaplanmasını ve azaltımasını amaçlamaktadır. Bu yolla gerçekleştirilecek afete duyarlı ve dirençli-dayanıkı bir toplumun inşasında (olabildiğince az etkilenme ve etkilerden hızla kurtulup eskisinden daha kaliteli yaşam çevreleri kurma) yerel yönetimlere ve sivil toplum kuruluşlarına büyük sorumluluklar düşmektedir. Ancak genel yönetim kültüründe yetki devri geleneği zayıf olan toplumsal sistemlerde yerel eyleyicilerin (aktör, fail) kendilerinden beklenen sorumlulukları yerine getirmelerine yarayacak bilgi, beceri ve deneyimleri (yani kapasiteleri) yeterince gelişmemektedir. Oysa depreme karşı direnç/dayanıklıık, ancak kırılgan grupların oluşturdukları taban örgütlerinin kapasiteleri gelişmişse gerçekleştirilebilir. Peki Van'da 2011 depremlerine kadar engelli grupları (için) kayda değer bir hazırlık yap(ı)mamışken, son sekiz yılda herhangi bir adım atılmıs mıdır; atılmışsa bunun içeriği nedir? Bu soruyu afet risk yönetimi açısından şöyle de sormak olanaklıdır: 2009 Hyogo Eylem Çerçevesi'nin geliştirilmiş hali olarak algılanabilecek 2015 Sendai Çerçevesi'nin Türkiye'de resmen benimsenmesinin etkileri artık gözlenebilir hale gelmiş midir? Bu makalede bu sorulara cevap ararken, Van'daki belediye ve engelli derneklerinin çalışmaları irdelenerek yerel örgütlenmelerin engellilerin afete karşı farkındalıklarının ve dirençlerinin yükseltilmesine bulundukları katkılar, kendi kapasiteleri, kendi aralarında ve afetle ilgili diğer kuruluşlarla yürüttükleri iş birlikleri, yapılan bir ampirik araştırmaya dayanarak sorgulanmaktır. Araştırmanın verileri 2018-2019'da derinlemesine görüşmelerle toplanmış ve nitel analize tabi tutulmuştur. Bulgular, Van'da engellilikle ilgili yerel örgütlerin, toplumun genelinde olduğu gibi afete yönelik farkındalıklarının zayıflığına, kendilerini sorun giderecek güçte eyleyiciler olarak görmediklerine ve bu yönde bir değişimi teşvik eden bir sosyo-politik iklimin eksikliğine işaret etmektedir. Makalede, engelli örgütlerinin çok boyutlu güçlenmesiyle bu sorunların aşılabileceği savunulmakta; bu doğrultuda, tabanda örgütlenmelerini ve yatay ilişkilerini geliştirebilecek iş birlikleri içinde afete hazırlanmalarını kolaylaştıracak bir dizi öneri geliştirilmektedir. Bu çalışma, Türkiye ölçeğinde engellilere yönelik dirençlilik çalışmalarına Van'ın yerel ortamından derlenmiş güncel ve gerçekçi katkılarda bulunmaktadır.

Anahtar Kelimeler: Afet, Dirençlilik, Sivil Toplum, Engellilik, Van

\section{Disaster Resilience of Handicapped People and Local Organizations in Van}

\begin{abstract}
\footnotetext{
${ }^{1}$ Sosyoloji Bölümü, Karamanoğlu Mehmetbey Üniversitesi, Karaman

${ }^{2}$ Sosyoloji Bölümü, Karamanoğlu Mehmetbey Üniversitesi, Karaman *ilgili yazar / Corresponding author: emel.sonkaya@afad.gov.tr Gönderim Tarihi: 26.05.2019

Kabul Tarihi: 29.06.2019
}

Turkey's disaster management approach has been going through a transformation from crisis management to risk management during the last decade. Risk management approach is based on a participatory organization and its objective is to identify potential hassards before dissasters and mitigate or prevent them. Local administrations and civil society organizations assume vital responsibilities towards these ends in disaster resilient societies. However local actors, such as grass roots organizations of vulnerable groups, do not have capacity (knowledge, skills and experience) for 
accomplishing expected responsibilities in such societal systems which do not delegate power to local bodies. As such, there was almost no preparedness regarding the handicapped people's resilience during the Van earthquakes in 2011 despite good guidence for action to combat disasters provided by the Hyogo Framework since 2009. Afterwards Turkey also officially adopted the Sendai Framework in 2015, which was an improved version of the Hyogo Framework. Now one may ask as to what extent the positive effects of these international guides for action become visible in practice in a local setting, Van. This article provides answers as to whether the municipality and civil society organizations in Van help increase disaster awareness and preparedness among handicapped people, and whether their organizational capacities and cooperation with other collective entitites have increased towards resilience. The qualitative research is based on data collected by in-depth interviews with the representatives and members of these organizations during 2018-2019. Research findings indicate local organizational capacieties and bottlenecks as well as possible solutions to main obstacles towards community resilience. It is expected that these updated and realistic findings derived from a local setting will contribute to the design of a comprehensive program for increasing the resilience level of the handicapped people living in Turkey's disaster zones.

Key Words: Disaster, Resilience, Civil Society, Disabilities, Van

\section{Giriş}

Türkiye'de sürekli doğa kaynaklı afetler meydana gelmekte ve bunlar toplumda önemli hasar ve kayıplara yol açmaktadır. Afetlerin etki düzeyi (fiziki, ekonomik, toplumsal yönden verdikleri zarar) ile meydana geldikleri toplumların hazırlık düzeyi doğru orantılıdır, çünkü afete hazırlıklı toplumların afete karşı direnme gücü ve dayanıklılığı (etkileri bertaraf ederken toplumun yeniden yapılanmasını eskisine göre daha dirençli hale getirme kapasitesi) daha fazla olmaktadır (Ergünay, 2009). Bunu tersinden okursak; toplumların ve bireylerin afetler karşısındaki bilgi, deneyim, örgütlenme ve kaynak yetersizlikleri, toplumları veya belirli toplumsal kesimleri krizler karşısında savunmasız (kııılgan, zarar görebilir) hale getirmektedir.

Türkiye'de geçmişten bugüne değin meydana gelen doğa kaynaklı afetlerde en çok hasara neden olan depremlerdir ve hemen her yıl, büyüklüğü 5.0 ile 6.0 arasında değişen en az bir deprem kaydedilmektedir (AFAD, 2014: 11; Gökçe, Özden, Demir, 2008: 16). Depremlerden etkilenme düzeyi ve biçimi toplumdan topluma kısmen değişse bile, en çok dezavantajlı (kırılgan) grupların etkilenmesi neredeyse her toplum için geçerlidir (Açıkalın 2017a; Saygılı, 2011; SFDR, 2015: 5; Buluş Kırıkkaya ve Gerdan, 2018). Kırılgan/dezavantajlı kesimler arasında, belli kapasite ve kaynaklardan yoksun kadınlar, hamileler, engelliler, yaşlılar, çocuklar ve sığınmacılar/yabancılar ilk akla gelenlerdir. Bu kesimlerden bireyler bir kriz ortaya çıktığında veya beklenmedik sorunlarla karşılaştıklarında, kendilerini kriz ortamından uzaklaştırabilecek adımları atamaya bilmektedirler. Örneğin, engelli bireyler bir deprem anında kendi başlarına binalardan uzaklaşmayabilmekte, seslerini başkalarına duyurmayabilmekte veya krizin içeriğini kavramayabilmektedirler. Ayrıca günlük yaşamdan uzak olmaları ölçüsünde kriz durumlarında nerelere başvurabilecekleri veya sığınabilecekleri hakkında bilgi sahibi olma olasılıkları da azalmaktadır. Bu ve benzeri nedenlerle, genelde kırılgan gruplara, özelde engellilere ve yakın çevrelerine yönelik kapasite geliştirme çalışmalarının afet öncesinden başlaması, ayrıntılı olması, tekrar edilmesi ve sonuçlarının yakından izlenmesi büyük önem taşımaktadır.

Sendai Çerçevesi'nin (2015) önemle üzerinde durduğu noktalardan biri, toplumsal kırılganlıkların (yani toplumsal eşitsizliklerin), doğal tehlikelerin doğa kaynaklı afetlere dönüşme riskini artırdığıdır. Kırılganlık, sağlıktan okuma-yazma becerisine, günlük sosyal hayata aktif katılımdan, gelir kaynaklarına ve sigortalı işe erişime kadar birçok göstergenin ortak etkisi olarak ortaya çıkmaktadır (Okay ve İlkkaracan, 2018; Özceylan ve Coşkun, 
2012a). Bu gibi göstergeler bireysel özellikler gibi görünse bile, aslında toplumsal eşitsizliklerin sonucudurlar (Açıkalın, 2017a). Bu yüzden tehlikelere, risklere ve toplumsal kırılganlıklara/eşitsizliklere yönelik farkındalıklar (veya duyarlılıklar), afetlerle mücadelede etkin politika ve eylemleri geliştirmenin ön koşulu olmaktadır.

Kırılganlıkların azaltılması için afet yönetiminde atılan adımlardan biri Hyogo Eylem Çercevesi (2005-2015)'dir. Bu çerçevede, sürdürülebilir kalkınma, yoksulluğun azaltılması, iyi yönetim ve afet riskinin azaltılması amaçları yer almaktadır. Bu eylem çerçevesinin son bulmasıyla, Hyogo'nun devamı niteliğinde olmakla birlikte daha da geliştirilen Sendai Afet Risk Azaltma Çerçevesi (2015-2030) dünyadaki ülkelerin büyük çoğunluğu tarafından 2015 'te kabul edilmiştir; Türkiye bu ülkelerden biridir. Sendai Çerçeve'sinde vurgulanan noktalar arasında; afet risk yönetimlerinin çok boyutlu, katılımcı ve kapsayıcı olmasının yanında hesap verebilirliği ve buna bağlı olarak bilgi üretme-kullanma-yayma kapasitesi de yer almaktadır. Katılımcı bir yapılanmaya dayanan afet risklerinin yönetimi yaklaşımı, afet öncesi aşamada mevcut tehlikelerin kavranması, bu tehlikelerden doğabilecek zararların hesaplanması ve azaltılması (veya risklerin ortadan kaldırılması) amacıyla, afete duyarlı ve dirençli bir toplumun oluşturulmasını içermektedir (Varol ve Kırıkkaya, 2017). Yerel yönetimlere ve sivil toplum kuruluşlarına bu işlerin başarılmasında merkezi bir rol ve büyük sorumluluk düşmesi, kapasite geliştirilmenin bu çok boyutlu ve kolektif (toplumsal) niteliğinden kaynaklanmaktadır (Açıkalın, 2018).

Türkiye'de özellikle 2011 Van depremlerinin ardından bu bütünlüklü bakış açısı daha sık kullanılmaya başlanmıştır. Bu sayede, afet oluşmadan afeti düşünerek, afet anı ve sonrası için hazırlık yapma fikri daha derinlikli şekilde anlaşılmış, afete hazırlık yapmanın kapasite geliştirmek olduğu hakkında farkındalık düzeylerinde artış kaydedilmiştir. Bu noktada Türkiye'nin afet yönetiminden beklenti, artık bu sözlerin hakkını veren uygulamaların yaygınlaşmasıdır. Bununla ilgili olarak belli ölçüde hâlâ sorunlu olan nokta, "kapasite"nin aslen bireysel düzeyde ve bilgi aktarımıyla oluştuğuna ilişkin kanının sürmesidir (Açıkalın, 2017b; 2018). Van'da 2011'deki depremlerden bu yana yaşananlar, sözlerin uygulamalara yansıtılması konusunda ilginç bir örnek sunmaktadır.

Türkiye Deprem Bölgeleri Haritası'nda (AFAD, 2018) Van'ın toprakları 0,0-0,5 tehlike oranı arasında ve 0,2-0,4 tehlike ivmesinde yer almaktadır; yani bir bakıma Van'ın tamamı deprem riski altındadır. Özceylan ve Coşkun (2012b), Türkiye'deki sosyo-ekonomik zarar görebilirlik düzeylerini yansıtan beş kategori belirlemişlerdir; bunlardan en fazla zarar görebilirlik düzeyini temsil eden beşinci kategoride 10 il bulunmakta ve Van bunlar arasında dördüncü sırada yer almaktadır. Bu yüksek risk altındaki alanda 2017 yılı itibariyle 18.688 engelli bulunmaktadır (Eliöz vd., 2017). Ama bunların nerede, nasıl ve ne yaptıklarına ilişkin yeterli bir kayıt bulunmamaktadır: Bu araştırma dolayısıyla AFAD ve diğer resmi kuruluşlardan edindiğimiz bilgi, yalnız Valilik'te engelli bakımı dolayısıyla para alanların listesinin olduğu yönündedir. Oysa, Birleşmiş Milletlerce İsviçre'de yapılan en son dünya forumunda bir kez daha, "geçerli bilgi üretimi ve dağıtımının" hesap verebilir etkin risk yönetiminin ön koşullarından biri olduğu tekrar vurgulandı (PreventionWeb, 2019).

Bu bağlamda 2011 yılında Van'da meydana gelen iki depremde engellilerin ne yaptıklarından daha fazla önem kazanan soru, yeni bir depremde ne yapacaklarını bilip bilmedikleridir. Bu sorunun cevabı, 2015 ’ten beri Türkiye'deki somut adımları etkilediği izlenimi edindiğimiz Sendai Çerçevesi'nin Van'daki engellilerin depreme veya daha genel anlamda herhangi bir afete hazır hale gelmelerine bir katkısı olup olmadığına ışık tutacaktır.

$\mathrm{Bu}$ çalışmada bu sorulara cevap ararken, Van'daki belediye ve engelli derneklerinin çalışmaları irdelenerek, yerel örgütlenmelerin engellilerin afete karşı duyarlılıklarının ve dirençliliklerinin yükseltilmesine bulundukları katkılar, kendi kapasiteleri, kendi aralarında ve afetle ilgili diğer kuruluşlarla yürüttükleri iş birlikleri sorgulanacaktır. 


\section{YÖNTEM}

Bu araştırma, Van'daki engellilere hizmet veren yerel kuruluşların (sivil toplum örgütleri ve belediye) 2019 itibariyle afete karşı hazırlık ve dayanma kapasitelerini anlamayı amaçlamaktadır.

Van Dernekler İı Müdürlüğü kayıtlarına göre Van'da 2019 Mayıs'ı itibariyle, üçü ilçelerde (Erciş, Çaldıran ve Edremit) olmak üzere toplam 12 faal engelli derneği veya kulübü vardır. Büyükşehir belediyesine bağlı Engelsiz Yaşam Akademisi ve Büyükşehir Engelli Birimi aktiftir. Ayrıca kapanmış veya başka bir yapılanmaya dönüşmüş birkaç dernek de bulunmaktadır. Deprem veya afet konusunda ise Van'da bugüne kadar yalnız bir dernek kurulmuştur ve o da şu an kapalıdır. Bu yerel yapılanmaları "hükümet-dışı kuruluş" ve Sivil Toplum Kuruluşu (STK) olarak düşünmek olanaklıdır. Böylece Van'da, engellilik ve deprem temalarıyla ilişkisi kurulabilecek aktif veya artık kapanmış olan 20'ye yakın STK'nın izi sürülebilir durumdadır.

Bu araştırmada bu kuruluşlardan 12'sine ulaşılmıştır. Kuruluşların seçim ölçütleri; deprem veya engellilikle ilgili olmak, hükümet-dışı kuruluş niteliğinde olmak ve görüşmeye istekliliktir. Görüşmeler, kuruluşlar arasındaki farkılaşmanın çok sınırlı olduğuna işaret ettiğinden, daha fazla STK'ya ulaşma gayreti gösterilmemiştir (Creswell, 2016; Neuman, 2014).

Görüşmeler, kuruluşların dağılımına paralel olarak Van kent merkezinde yoğunlaşmıştır. 2018'in Aralık ayından 2019 Mayıs'ına kadar kesintilerle; 12 kuruluşu temsil eden birer yönetici ve iki üye ile derinlemesine görüşmeler gerçekleştirilmiştir. Görüşmelerin çoğu yüz yüze yapılmış, fakat bir saati aşkın telefon görüşmelerine de başvurulmuştur. Her katıııcının konu başlıklarını serbestçe tartışması sağlanmış, ardından veriler kaydedilip tematik şekilde sınıflanarak, kolektif düzeyde (kuruluşlar düzeyinde) analiz edilmiştir.

Araştırmada örgütlerin kapasitesi, üye sayıları, finans kaynakları, birbirleriyle ve farklı kuruluşlarla dayanışmaları temelinde irdelenmiştir. Depreme hazırlık adına engellilere ve ailelerine yönelik bilgilendirme, deneyim kazandırma, ağlara katma ve diğer güçlendirme etkinliklerinin düzenlenip düzenlenmediği, yönelimlerin nedenleri ve daha etkin sonuçlar için yapılabilecekler hakkında bilgi derlenmiştir. Bir başka kapasite göstergesi olarak 2011 depremlerindeki deneyim hakkında bilgi alınmıştır.

\section{VAN'DA DEPREM VE ENGELLILER KAVŞAĞINDA ÖRGÜTLENMELER}

Bu bölümde önce kuruluşların temel özellikleri, etkinlik alanları, üyelikleri, diğer kuruluşlarla iş birlikleri, finansal kaynakları ve sonra deprem deneyimleri ve depreme hazırlık adına yaptıkları aktarılacaktır.

\subsection{Temel Özellikler}

Tablo 1: Kuruluşların Temel Özellikleri

\begin{tabular}{|l|l|l|l|}
\hline Birim İsmi & $\begin{array}{l}\text { Kuruluş } \\
\text { Yılı }\end{array}$ & Engellilik Türü & $\begin{array}{l}\text { Üye Sayısıl } \\
\text { Aktif Üye* }^{*}\end{array}$ \\
\hline $\begin{array}{l}\text { Van Bedensel Engelliler Spor } \\
\text { Kulübü }\end{array}$ & 2005 & Tüm engelliler & $200 / 25$ \\
\hline Altınokta Körler Derneği & 2006 & Görme engeliler & $147 / 30$ \\
\hline $\begin{array}{l}\text { Van İşitme Engeliler Eğitim } \\
\text { Kültür Gençlik ve Spor Kulübü }\end{array}$ & 2010 & İşitme engelliler & $65 / 47$ \\
\hline $\begin{array}{l}\text { Zihinsel Engelliler Yeşeren } \\
\text { Umutlar, Bedensel Engelli Der. }\end{array}$ & 2010 & $\begin{array}{l}\text { Zihinsel ve } \\
\text { bedensel engelliler }\end{array}$ & $100 / 20$ \\
\hline
\end{tabular}




\begin{tabular}{|c|c|c|c|}
\hline Altınokta Spor Kulübü & 2011 & Tüm engelliler & $38 / 15$ \\
\hline $\begin{array}{l}\text { İsitme Engellileri ve Aileleri } \\
\text { Derneği }\end{array}$ & 2011 & İşitme engelliler & $1200 / 40$ \\
\hline Büyükşehir Engelli Birimi & 2014 & Tüm engeliler & Paylaşılmadı \\
\hline Engelsiz Yaşam Akademisi & 2015 & Tüm engeliler & $\begin{array}{l}\text { Üyelik sistemi } \\
\text { yok }\end{array}$ \\
\hline $\begin{array}{l}\text { Erciş Bedensel Engelli Aileleri } \\
\text { Yardımlaşma, Dayanışma Der }\end{array}$ & 2017 & Tüm engelliler & $90 / 25$ \\
\hline GEA Arama Kurtarma Derneği & 1994 & Deprem odaklı & $\begin{array}{l}\text { 2018'de } \\
\text { Kapandı }\end{array}$ \\
\hline Van Tüm Engelliler Derneği & 2014 & Tüm engeliler & $\begin{array}{l}\text { 2016'da } \\
\text { Kapandı }\end{array}$ \\
\hline Engelli Meclisi & 2010 & Tüm engeliler & $\begin{array}{l}2016 \text { 'da } \\
\text { Kapandı }\end{array}$ \\
\hline
\end{tabular}

*Her üç etkinlikten ikisine katılan veya etkinliğin düzenlenmesinde rol alan.

Yukarıdaki tabloda görüleceği üzere sekiz STK depremden önce (2011'de kurulanlar da deprem öncesinde), dördü ise depremden sonra kurulmuştur; kapanmaların hepsi yakın tarihlidir. En eski kuruluş 1994'te kurulan GEA Arama Kurtarma Derneği iken en yenisi 2017'de kurulan Erciş Bedensel Engelli Aileleri Yardımlaşma ve Dayanışma Derneği'dir. Kuruluş itibariyle en eski olan GEA maddi yetersizlik ve gönüllü bulamamaktan 2018'de kapanmıştır. 1990'larda kurulan bir başka STK olan Bedensel Engelliler Derneği ise 2005 'den bu yana Bedensel Engelliler ve Spor Kulübü olarak etkinliklerini sürdürmektedir.

STK'lardan yalnız dördünün kökeni Van dışı bir ildir (Altınokta Körler Derneği, Altınokta Spor Kulübü, İşitme Engellileri ve Aileleri Derneği ve GEA Arama Kurtarma Derneğidir); diğerlerinin ilk kuruluş yeri Van'dır.

Van'da depremden önce ve sonra, depremle ilgili tek formel kuruluş GEA Arama Kurtarma Derneği'dir; depremle ilgili olduğundan araştırma kapsamına aldığımız bu kuruluşun engellilerle ilgili bir etkinliği veya engelli üyesi olmamıştır. Ayrıca Erciş’te deprem sonrasındaki iyileş(tir)me döneminde çocukların psikolojik yönden rahatlamalarına destek olan bir gençlik inisiyatifi bir dönem aktif olabilmişti.

Araştırma kapsamındaki diğer STK'lar engellilere ve bazıları da ailelerine de yöneliktir. Görüşmelerimiz, depremden önce en az altı engelli derneğinin varlığına işaret ediyor. Depremden sonra ise engellilere yönelik beş kuruluş açılmış, bazıları da açııp faaliyetini sürdüremeyerek kapanmıştır. Engellilerle ilgilenen STK'ların üçü belli bir veya iki türe yöneliktir (görme, işitme, zihinsel ve bedensel engellilik), diğerleri tüm engellilere hitap etmektedir.

Kuruluşların yalnız yedisinden üye sayıları alınabilmiştir; ikisi kapandığından bu ayrıntı hatırlanmamaktadır, biri üye sayısını paylaşmak istememiştir veya bu konuda bilgi yoktur, bir diğeri ise bir eğitim yapılanması olarak üyelik sistemine göre çalışmamaktadır.

Bilgi alınabilenler arasında en çok kayıtı üyeye İşitme Engellileri ve Aileleri Derneği sahiptir ve en az üyesi olan Altınokta Spor Kulübü'dür. Yedi STK'nın ortalama aktif üye sayısı yaklaşık 30'dur. Oysa 2000'lerin başlarında engellilerin günlük yaşamda görünürlükleri bile sorunluydu: Örneğin, AB destekli Doğu Anadolu Kalkınma Programı kapsamında Van'da hibe projesi yürüten iki engelli STK'sından biri bu sorunun önemini vurguluyordu (Kıran ve Rashem 2007: 28-29). Aradan geçen 15-20 yılda dernek ve aktif üye sayısı bakımından engellilerin ulaştıkları noktayı önemsemek gerekmektedir. Ayrıca görüşmelerimizde, üye sayılarının resmiyette fazla olmasının, prosedürleri ve bürokrasiyi artırdığına ilişkin bir açıklamayı da kaydettik. Epey fazla üyesi olan bir derneğin temsilcisi şöyle söylemişti: 
...biz resmi kayıt için göstermiyoruz. Şimdi 1200 üyemiz var ama resmiyette 40 kişi gösteriyoruz. Çünkü prosedürde çok şey değişiyor biz de gerek duymuyoruz.

Kuruluşlara üye olmak isteyenlerin bir kısmının kuruluşlar hakkında çevrelerinden bilgi alarak gelmiş oldukları anlatılmıştır. Kuruluş temsilcileri bu durumdan gayet hoşnut gözükmektedirler:

Birçok üyemiz kendisi gelip oldu. Aileler özel eğitimcilerden duyup geliyorlar. Gönüllü gelen çok var.

Kuruluşların yönetimlerinde giderek daha fazla sayıda engelli bireyin yer alması da bu alandaki olumlu gelişmelerden biridir. Bir başka olumlu nokta, beş STK'nın aynı binayı kuruluş merkezleri olarak paylaşmasıdır; diğerleri yalnız kendilerine ait mekanlarda etkinliklerini sürdürmektedirler.

\subsection{Etkinlikler ve İş birlikleri}

Engelli STK'larının en sık dile getirilen amaçları sosyalleşme ve dayanışmayı sağlamak, üyelerine maddi yardımda bulunmak, becerilerini geliştirmelerine destek olmak, sorunlarına çözüm aramak ve bu doğrultuda hak arayışında bulunmaktır. Engellileri doğrudan ilgilendiren en önemli etkinliklerden bazıları, tekerlekli sandalye dağıtmak, meslek edinmeleri için kurslar ve hobi edinmeleri için faaliyetler düzenlemek ile aileleri destekleyici bilgiler aktarmaktır. Engelli bireylerin birbirleriyle tanışıp sosyalleşmesi amacıyla düzenlenen etkinlikler arasında piknik ve kamp yapmak, okey ve satranç oynamak, yürümek, yemek yemek ve film izlemek yer almaktadır. Daha uzmanlaşmış bir alan olarak engelli spor kulüplerinin sosyalleşmeye katkıda bulunmak ve beceri geliştirmek ana başlıklarının altındaki özgül amacı, engelli bireylerin sporla ilgilenmelerini sağlamak ve buna imkân yaratmaktır.

Görüşmeler, sivil toplum örgütlenmesi olmanın anlamına uygun şekilde, engelli kuruluşları arasında çeşitlenmiş dayanışma biçimlerinin örgütlendiğine işaret etmektedir. Bunlar arasında, mekân paylaşımı önemli bir yer tutmaktadır. Kiralarını projelerden karşılayan bazı kuruluşlar, mekânlarını paylaştıkları diğer kuruluşların kira harcamasına katılmasını talep etmemektedir.

Bunun ötesinde, kuruluşların, ortak etkinlik düzenlemek ve birbirinin etkinliğine katılmak gibi dayanışma çabaları olmaktadır:

Engelli gününde beraber olduk. Beraber piknik yaptık. Spor aktivitelerine, maçlara katıldık.

Diğer engelli derneklerle kardeş kurumlar gibi çalışıyoruz. Elimizden geldiğince iletişimde olmaya çalışıyoruz. Zaten haftada bir de olsa mutlaka konuşuruz. Etkinliklerimizden haberdar ederiz... Beraber proje yazdığımız dernekler oldu... Tüm etkinliklerimize katılım sağlarlar. Proje yazdık, onları da engelliler için yapılan eşit haklar eğitimine götürdük.

Üye sayısını artırmak için dernekler birtakım etkinlikler yapmaktadır. Etkinlikleri yaparken STK'lar çeşitli kuruluşlardan destek alıp onlarla iş birliği kuruyorlar.

IŞ-KUR aracılığıyla kurs [bilgisayar] veriyoruz. Kursa gelenler üye olmak istiyor. Bunun için ekstra bir çabamız yok... projelerle sesimiz daha fazla duyuluyor ve üyelerimiz gitgide artıyor.

Çeşitli kurslar düzenliyoruz (işaret dili, bilgisayar, müzik vb.) bu kurslara tüm engelli bireyler katılım sağlıyor [diğer kuruluş/arın üyeleri]. Bunun yanında derneğin armasının olduğu bir kitap ayracı bastırdık; tüm etkinliklerde dağıtıyoruz. Sonra maçlarımıza birçok kişi seyirci olarak katılıyor, onlarla diyalog kuruyoruz. Zaten kim maçımızı izlemeye gelse illaki merak edip yanımıza geliyor.

Ancak kuruluşlar arasında çıkara dayalı bir rekabetin veya sivil toplum anlayışındaki bir farkın bu dayanışma havasını "bulandıran" bir rol oynadığını, toplumun genelindeki dışlanmışlığın, 
engelliler topluluğunun içinde de belli ölçüde yeniden üretildiğini gösteren durumlar bulunmakta:

Birbirimizle iletişimimiz var, iki sene önce Gevaş Kızılay Kampı'nda bir haftalık tatil yaptırdık engellilere, Türkiye'nin her yerinden gelenler oldu. Onun dışında bir de Engelli Günleri'nde buluşuyoruz. İlişkiler biraz menfaat üzerine kurulu; mesela, geçenlerde yeni seçilen belediye başkanını ziyarete giden engelli dernekleri olmuş, ama hiç bize haber etmediler. Kendi menfaatlerini düşündüler, diyorlar, belki belediye onlara değil de bize yardım eder.

$\mathrm{Bu}$ anlatımda örtük olan "himaye arayışı" ve bunun bir ayrım/kayırma gerektirdiği fikri, aşağıdaki anlatımdaki "aktif özne olamayış" haliyle veya bu yöndeki pek de temelsiz olmayan yaygın toplumsal kanıyla uyumludur:

Engellileri dilenci gibi görüyorlar, kurumlar pek kale almıyor. Hepimiz bir olsak, birlik olsak, kimse bize bunları yapamaz, ama işte bazı dernekler gidip dileniyor. Onlar da zannediyor ki herkes aynı..

Kuruluşlar belli ölçüde birlikte iş yapma deneyimine ve yönelimine sahip olsalar bile, afetle veya depremle ilgili ortak bir etkinlik gerçekleştirmemişlerdir. Bunun nedeni bir yandan STK'ların deprem gerçeğinden uzak olmaları, bir yandan da ilgili kamu kuruluşlarının afete hazırlık alanına ve/veya engellilik konusuna en az STK'lar kadar uzak olmalarıdır. Dolayısıyla STK'lar deprem eğitimiyle ilgili ilk adımı yetkili kuruluşlardan beklerken, konuyla ilgili kamu kuruluşlarının başında gelen AFAD ise derneklerden deprem eğitimiyle ilgili talep beklemektedir. İlk bakışta karşılıklı bir iletişimsizlik olduğu sonucuna varılabilir. Ancak olgunun iki tarafındaki eyleyiciler açısından da durum bundan daha sorunludur.

Kuruluşlar deprem eğitimi ve depreme hazırlık gibi alanları yetkili gördükleri kurumlara bırakmıştır; bunun anlamı, kendilerini yetkin, yetişkin, olgun birer eyleyici olarak algılamak yerine, himayeden (ataerkinin en temel özelliğinden) yararlanması gereken çaresiz nesneler olarak algılamalarıdır. Toplumun genelinde "engellilerin dışlanmışlığı" veya "yok sayılması" sorunu, yeniden farklı biçimlerde üretilmektedir. Buna karşılık kamu kuruluşlarından belediye, valilik ve DAKA bazı oluşumlara destek vererek engellileri önemsediklerini gösterseler bile, onların afetle ilgili bir iş yapabileceğine ilişkin inançları olmayabilir veya kendilerinin deprem farkındalığı oldukça düşük olabilir. Bu noktalar, ayrıca araştırılması gereken önemli konular olduğunu göstermektedir.

\subsection{Finans Kaynakları}

Araştırma kapsamında aktif kuruluşlar arasında üyelerinden aidat alan ve bununla geçinmeye çalışan bulunmamaktadır. STK'ların ikisinde masrafları yönetim kurulu üyeleri karşılamaktadır. Büyükşehir Belediyesi bünyesindeki Engelsiz Yaşam Akademisi ve Engelli Birimi'nin mekân sorunları yoktur ve bir etkinlik yaparlarsa bunu Belediye karşılamaktadır. Beş kuruluş ulusal ve uluslararası proje hibelerine dayanarak kendilerini finanse etmektedirler. Bunlar arasında ulusal hibe programları Valiliğin yönettiği Sosyal Destek Programı (SODES) ve Doğu Anadolu Kalkınma Ajansı'nın (DAKA) programlarıdır. Uluslararası düzeyde ise Avrupa Birliği $(A B)$ 'nin finanse ettiği Sivil Düşün Programı yer almaktadır.

STK'ların en önemli giderlerinin kira olduğu anlaşılmaktadır.

Bunun yanında yaptıkları etkinlikler de belli bir ölçüde kendilerini zorlamaktadır, ama bununla ilgili giderlerini çoğunlukla üç kaynaktan karşılamaktadırlar. Bunlar, belediyeden aldıkları yardım, açtıkları kurslar karşılığında Milli Eğitim Bakanlığı'ndan aldıkları yardım ve projelerde masraflarını yaptıktan sonra artırdıkları paradır. Erciş'teki dernek prefabrik bir binada etkinliklerini sürdürdüğünden kira gideri olmamaktadır. Yalnız beş kuruluşun kendilerine ait 
mekânları bulunmaktadır. Diğer dört kuruluş ikili olarak ortak mekân kullanmaktadır. Ortak mekânı kullananların ikisi giderlerini ortak karşılarken, diğer ikisinde bunu bir taraf karşılamakta ve o da geçimini projeler üzerinden sağlamaktadır.

Araştırma kapsamındaki kapanmış olan iki STK (GEA ve Van Tüm Engelliler Derneği) aktifken harcamalarını üyelerinden aldıkları aidatlarla karşııyorlarmış ve aidat toplayamamaları kapanmalarına yol açan iki nedenden biri olmuş. Aidat almamalarını bir kuruluş temsilcisi, "zaten ailelerin durumu pek parlak değil. Kendileri yardım bekler durumdayken nasıl onlardan aidat alabiliriz ki?" şeklinde açıklamıştı. Bu iki derneğin kapanmasında aynı zamanda, üye olacak gönüllü bulamamalarının da etkisi olmuştur. Bu durum, hem genelde Van'daki sivil toplum hakkında, hem de özelde sivil toplumdaki deprem farkındalığı hakkında önemli ipuçları vermektedir.

\subsection{Deprem Deneyimleri}

Görüşmelerimiz engelliler açısından depremin zorlu bir deneyim olduğunu, Engelli STK'larının az da olsa yardım dağıtım sürecine katılığını, göç sürecine katılımın yoğun ve izlenimlerin olumlu olduğunu ortaya koyuyor.

Katılımcılardan biri deprem anındaki durumun vahametini belirtmek için "kâbus" benzetmesini yapıyor:

Benim için ve tüm engelliler için kâbus gibiydi. Adam sakattı, kördü; nasıl evden çıkacaktı? Sivil savunma gelip öncelik vermedi. Van'da bugün sekiz bin engelli var. Bunlar depremde neler yaşamış, ne eziyetler çekmiş. Bunları yazmaya sayfalar yetmez.

Bedensel engelli bir katılımcı depremde yaşadığı bir kazadan dolayı durumunun daha kötü olmasını bilgisizliğiyle açıklıyor:

Deprem olduğunda annem ve babamla yemek masasında oturuyorduk. Deprem olunca ne yapacağımızı bilmediğimiz için kaçmaya başladık ben o ara merdivenlerden aşağı kadar yuvarlandım ve kalçamdaki platini çatlattım. Ondan sonra mecbur protez bacağa mahkûm kaldım.

Açıkalın'ın (2017b: 113) Van'daki yoksul kadınlarla deprem sonrasındaki sekizinci ayda yaptığı görüşmelerin birinde; deprem anında iki bedensel engelli kızını evden çıkarmaya çalışan 62 yaşında bir annenin çektiği zorluk anlatılmaktadır. Aradan sekiz ay geçmesine rağmen, o anın halen etkisindeki kızlar, annelerinin o anki çaresizliklerinden ve korkularından bahsetmesini istememişlerdir.

Yalnız başına kızlarının kent dışına gidişini de ayarlamakta büyük sorunlarla karşılaşan bu kadının yaşantılarına rağmen, görüştüğümüz engelli derneklerinin temsilcileri, depremden çok kısa süre sonra Valiliği kendilerini il dışına (Mersin, Adana, İstanbul, Ankara ve İzmir) çıkardığını ve çoğu engelli için de bunun tercih edilen çözüm olduğunu anlatmışlardır.

Depremden sonra Valilik 250 TL harçlık verdi, biletimizi kesip bizi İstanbul'a gönderdi...Valiliklerin misafirhanelerinde (Istanbul) kalıyorduk. Sonra (1 yıl) Van'a geri geldik. O zaman da oradaki Valilik bizim biletlerimizi karşıladı.

Kuruluş temsilcilerinden biri Mersin'e gönderilen engellileri ziyarete gitmiş̧tir. Memnuniyetini "Van'ın zenginleri bile orada kalır" cümlesiyle vurguluyor:

Ben Mersin'e ziyarete gittim. Baktım misafirhane o kadar lüks ki Van'ın zenginleri bile orada kalır. Üç öğün yemek veriyorlardı. Velhasıl çok güzeldi. 
Şüphesiz tüm engelliler kent dışına gitmemiştir: Çadır, prefabrik ve müstakil evlerde kalan engelli bireylerin de olduğu görüşmelerden anlaşılmaktadır ve bunlara yönelik bazı yardımlara engelli dernekleri aracı olmuşlardır.

Deprem anında ve sonrasında aktif şekilde iş gören üç kuruluş olmuştur. Bunlar, GEA Arama Kurtarma Derneği, Zihinsel Engelliler Yeşeren Umutlar Derneği ve İşitme Engellileri ve Aileleri Derneği'dir. Örneğin, İşitme Engellileri ve Aileleri Derneği işitme engelli bireylerin cihazlarının pilini sağlamıştır:

O zaman işitme engeliler için pil getirttik. Piller erken bitiyor ve hemen değiştirilmesi gerekiyor. Devlet karşıııor belli bir kısmını, ama pilleri alana kadar da can çıkartıyor. Pek fazla bir şey yapamadık, ama zaten o zaman herkes şehir dışına çıkmak zorunda kaldı.

Zihinsel Engelliler Yeşeren Umutlar Derneği bir iş adamının maddi yardımlarıyla çadırlarda kalan engellilere destek sağlamıştır. Nakdi yardımı bu dernek sadece üyelerine değil, tüm engellilere dağıtmıştır:

Bir tane iş adamı para gönderdi, dedi, engellilere dağııın. Biz de tüm engellilere dağıttık, sadece kendi üyelerimize değil. Adam öyle bir hayırsever ki, isminin hiçbir yerde anılmasını istemedi. Halen de arada yardımlar gönderir.

Çoğu zorluk içeren deprem deneyimlerinin bir farkındalık yükselişine kendiliğinden yol açmadığını, Van'daki diğer örnekler ve Türkiye'nin önceki deneyimleri kadar (Açıkalın 2017b) bu araştırmada görüştüğümüz engelli STK temsilcileri de doğrulamıştır.

\subsection{Deprem Eğitimleri}

Depremden sonraki süreçte, araştırma kapsamında faal durumda olan dokuz kuruluşun üyelerinden yalnız ikisi (GEA Arama Kurtarma ve Van İşitme Engellileri Eğitim Kültür Gençlik ve Spor kulübü) bir afet eğitimi almıştır. Aslında işitme engellilerin derneğinden beş üye de bilinçli bir şekilde değil, tesadüfen bu eğitime bir kereye mahsus olarak katılmışlardır. Ne var ki, bu katılım da yeterli farkındalığın oluşmasına elvermemiş ve böylece benzeri bir eğitimi üyeleri veya ilişkide oldukları bireyler için yaygınlaştırmayı düşünememişlerdir:

Sadece bir kere, o da tesadüfen deprem eğitimi aldık. Beş üyemle Gençlik Merkezi'ndeydik; dediler, "deprem eğitimi var," biz de katıldık. Ben tabii, üyelere tercümanlık yapıyordum... Sonradan hiç aklımıza gelmedi, tüm üyelere bu eğitimi verelim. Kimse de gelip demedi ki, size bu eğitimi verelim.

Kuruluşlardan hiçbirinin eğitim vermek/almak "akıllarından bile geçmemiş" olduğundan, deprem eğitimi için bir talepte bulunan olmadığı gibi, nedendir bilinmez, bu yönde çaba gösterebilecek kamu kuruluşlarının da aklına engelliler gelmemiştir:

Afetle ilgili herhangi bir eğitim almadık. Bu konuyu hiç düşünmedik... Biz de pek bilinçli değiliz afet konusunda.

Biz bunu hiç düşünmedik... zaten AFAD'dan da böyle bir teklif gelmedi. Ee tabii bizim de böyle bir talebimiz olmadı.

Araştırma kapsamındaki kuruluşlardan yalnız biri, kurumlar arası diyaloğu geliştirmek için AFAD ile iletişime geçmiştir. Bu amaçla dernek başkanı AFAD başkanını ziyaret etmiş, fakat sonrasında AFAD'dan olumlu bir karşılık gelmemiştir:

Afetle ilgili herhangi bir etkinliğimiz olmadı. Onlar (AFAD) bizi kaideye almıyor. Onlar engellilerin var olup olmadığını bile bilmiyorlar... Mesela AFAD başkanı[na] ... gidip sorun, Van'da kaç engelli olduğunu biliyor mu? ben ... [onun] yanına gittim, kendilerini davet ettim ama gelmediler... Engeliler gününde bile gelip bir şey demediler. 
Araştırma kapsamında AFAD ile görüştüğümüzde, AFAD'ın henüz herhangi bir engelli kuruluşuna afet eğitimi vermediğini kaydettik. Fakat bir talep olursa eğitim verebilecekleri de görüşmede belirtildi.

Kısacası görüşülen engelli kuruluşlarının temsilcileri ve üyelerinin anlatımlarından, engellilerin 2011 Van depremlerinde ve sonrasında çok ciddi sıkıntılar yaşadıkları anlaşılmaktadır. Buna rağmen engellilere hizmet veren sivil toplum örgütleri, iletişimde oldukları şahısların ve ailelerinin, yeni bir olası depreme karşı hazırlanmasına destek olmamışlardır. Bunun gerekliliğinin de farkında değillerdir. Engellilere hibe dağıtımı yapan kuruluşların ise, hibelere başvuru koşulları arasında depreme hazırlık konusunu belirterek bir farkındalık yaratılmasına destek olmak gibi bir çabası olabilirdi. Ancak bunun da gerçekleşmediği anlaşılmaktadır.

\section{SONUÇ VE ÖNERILER}

Doğa kaynaklı afetlerden biri olan depremler meydana geldikleri yerlerde çeşitli kayıplara ve hasara yol açmaktadır. Depremin can ve mal kaybı gibi olumsuz taraflarından en fazla dezavantajlı gruplar etkilenmektedir, bu gruplardan biri de engellilerdir. Olumsuz etkilerin azaltılması için depreme karşı direnç veya dayanıklılık geliştirmek gerekmektedir. Engelli bireylerin sürekli yardıma muhtaç pasif alıcılar şeklinde kalmaları gerekmemektedir; doğru örgütlenme, iletişim ve iş birliği sayesinde herkes gibi onlar da depreme direnebilecek kapasiteyi geliştirebilirler. Buna önce engellilerin ve yakınlarının ikna olması gerekmektedir.

$\mathrm{Bu}$ yöndeki çabalarda hiçbir aktörün birincil veya ikincil olarak belirlenmesine gerek yoktur: Merkezi yönetim kadar yerel yönetimler ve onlar kadar meslek örgütleri veya sivil toplumdaki gönüllü kuruluşlar da aktif şekilde sürece katılmalıdırlar.

Bu düşünceyle; biri Erciş'te 11'i Van merkezde olmak üzere 12 STK ile derinlemesine görüşme gerçekleştirerek kuruluşların kapasitelerini irdeledik. Kuruluşların etkinlik hayatına başlama ve kapanma tarihleri, deprem sonrası dönemin sivil toplum lehine işlemediğine dair bir ipucu olabilir. Fakat genelde engellilere yönelik alanın dikkate değer bir hareketlilik içinde olması (örn., açılıp kapananlar, birleşip ayrılanlar, kuruluşların çoğunun Van kökenli olması ve gönüllü üyelikler), yalnız engellilere yönelik olarak değil, genelde yerel sivil toplum adına olumludur. Engelli kuruluşlarının son 15 yılda sosyal alandaki görünürlüklerini artırmalarındaki başarı, giderek üye sayılarına ve üyelerin gönüllü ve aktif katılımlarına yansımaktadır. Projecilik, klasik yolla aidatlar aracılığıyla gelir edinemeyen STK'ların önemli bir kazanç kaynağı haline gelmiş görünmektedir. Bu çerçevede etkinliklerinde belli bir süreklilik kazandıkça toplumdaki görünürlükleri de artmaktadır.

STK'lar arasında uzunca bir süredir gelişmiş olan dayanışma alışkanlığı bu alandaki en önemli avantaj, bunun himaye alabilmek için dışlayıcı pratiklerle bozulması ise önemli bir tehdit noktasını oluşturuyor.

$\mathrm{Bu}$ araştırmada hem genelde sivil toplumun hem de engelli kuruluşlarının tabandan örgütlenme anlayışlarının da depreme yönelik hazırlık çabalarının da oldukça yetersiz olduğu ve afete karşı dayanma kapasitelerinin düşük olduğu anlaşılmıştır. Bunun bir uzantısı olarak, hakkında bilgi aldığımız 12 kuruluşun genelde afet ve özelde deprem farkındalığının yetersiz olduğu gözlemlenmiştir. Dolayısıyla kapasitelerinin ne olabileceği hakkında bu STK'ların temsilcilerinin bir fikirleri de bulunmamaktadır.

Belki de asıl sorun, engellilerin aktif şekilde günlük yaşamın bir parçası ve özerk-yetkin bireyler olabileceklerine ilişkin algının, toplumun geneli kadar engelliler arasında da yaygın olmamasıdır. Bu nedenle yalnız afete hazırlık gibi konular önemsenmemekle kalmıyor, sivil toplum aracılığıyla günlük yaşamın iyileştirilebileceğine ilişkin bir fikir de benimsenmiyor. Sivil 
yaşamın kendisi yerel ortamın kenarında yer alıyor. İyileştirmeye ilişkin alan daha çok yetkililere terk ediliyor.

Açıkalın'ın (2017b) Van araştırmasının sonuçlarıyla bu araştırmanınkileri birlikte değerlendirdiğimizde, çeşitli toplumsal kesimlerden bireyin yalnız kendisinin ve çevresindekilerin başına gelenlerden haberdar olduğu, bilgiye erişim güçlüğü karşısında özgül grupların durumunu merak bile etmekten vazgeçtiği anlaşılmaktadır. Buna paralel olarak engelli bireylerin nasıl zorluklarla karşılaştıkları da toplumun genelinde bilinmemektedir. Üstelik, toplumda engellilerin sesi olan kuruluşların da bu tür bir bilginin dolaşıma girmesine yönelik bir çabaları olmamış, bu tür bir bilginin kendilerine sağlayacağı yararı da yeterince değerlendirememişler. Bu durumda deprem olduğunda anlık çözümler üretilmeye devam edilecektir. Engellilik bir kırılganlık alanına işaret etmektedir, fakat bunun değişmesine katkı sağlamayan bir toplumsal-kültürel zeminin varlığı gözlemlenmektedir.

Kuruluşlardan bir deprem ve bir engelli derneğinin kapanma nedenlerinden biri gönüllü bulamaması iken, bazı derneklerin gönülü bulmakta zorluk çekmemesini iki açıdan yorumlamak olanaklıdır. Öncelikle, toplumsal kesimler ve bireyler bir örgütlenmenin kendilerine yararını anladığında onun içinde yer almaktadırlar; bu durum deprem/afet alanından çok engellilik alanından gerçekleşmiştir. Demek ki deprem ve afet konusunda toplumun bütününde olduğu gibi engelli topluluğu arasında da farkındalık çalışmalarına ağırlık vermek gerekmektedir. İkincisi, STK'ların, hitap ettikleri toplumsal kesimlerin ilgisini çeken etkinliklerle kendilerini görünür kılabildikleri anlaşılmaktadır. Demek ki, spor veya piknik gibi etkinliklerle bilgi aktarımı ve deneyim geliştirme etkinliklerinin birleştirilmesinde yarar vardır.

Bu noktada, var olan durumu iyileştirmek adına birkaç öneri sunmak gerekirse:

- Öncelikle Van AFAD'ın desteğiyle engelli derneklerinin liderliğinde Van'daki engelli bireylerin afet farkındalığını yükseltecek etkinlikler düzenlenebilir. YYÜ'deki Afet Yönetimi ve Deprem Araştırma ve Uygulama Merkezi ile Engelliler Araştırma ve Uygulama Merkezleri ve belediye de bu sürecin birer parçası olabilirler.

- Bu etkinlikleri tamamlayıcı şekilde, yine engelli STK'larının liderliği ve AFAD desteğiyle, kamu, özel ve sivil toplum kuruluşlarına yönelik engellilik ve deprem farkındalığı geliştirecek etkinlikler geliştirilebilir. Bu etkinliklerin çıktıları, bu alanlardaki yeni etkinliklere katkı şeklinde kurgulanabilir (örn., SODES ve DAKA projelerinde engelli kuruluşlarının ortaklaşmaları ile deprem hazırlık pratikleri yapmaları veya belirli mahallelerde engellileri saptamaları gibi).

- Van'daki engellilere ulaşmak için bir veri tabanı oluşturulması ve bu veri tabanı sayesinde afet eğitimlerinin sürekliliğinin sağlanması özel bir önem taşımaktadır.

- Veri tabanı belli zaman aralıklarında engelli elemanlarca güncellenebilir.

- Veri tabanı tüm engelli birimlerine açık olabilir; gerektiğinde Belediyeler ve Valilik ile paylaşılarak beraber iş yapılabilirlik zeminini oluşturabilir.

- Engelli STK'larını Türkiye Afetle Mücadele Planı (TAMP) yapım grubuna katmak hem onların toplumdaki görünürlüklerini artırır hem de aktifleşmelerine ve becerilerinin gelişmesine katkıda bulunur. STK'ların görünürlüklerinin artması ise beraber iş yapabilmeyi, sorumluluk bilincini ve iş yapabilirliği geliştirir. Bir bakıma direnç düzeyi artar.

- Dernekler arası iş birliğini geliştirmek ve iş birliği alanlarını çeşitlendirmek için kuruluşlar projeler hazırlayabilirler. Buna, DAKA, YYÜ, AFAD, Valilik (SODES) ve kapasitesi olan diğer kuruluşlar özellikle finansal ve diğer intiyaç duyulan alanlarda destek olabilirler.

- Engellilere hibe dağıtımı yapan kuruluşlar, hibelere başvuru koşulları arasında depreme hazırlığı belirterek bir farkındalık yaratılmasına destek olabilirler. Ancak yukarıda belirtildiği gibi öncelikle bu kuruluşların deprem/afet ve engellilik farkındalıklarının yükseltilmesine destek vermek gerekmektedir. 
- Eğer engelli STK'ları STK bilincini ve yönetim becerilerini geliştirmeyi kapasite gelişiminin bir parçası olarak görüyorlarsa, geliştirecekleri projeler doğrudan bu tür konuları da hedefleyebilir.

- Engellilerin ilgisini çekecek etkinlikler (piknik, spor, yemek organizasyonları, kamp kurma vb.) düzenleyip bu alanlarda bilgi aktarımı sağlanabilir.

\section{Kaynaklar}

Açıkalın, O. (2018). Bilim Toplulukları ve Sivil Toplum İşbirliğiyle Türkiye'de Depreme Dayanıklılık, 20. Yuvarlak Masa Toplantısı. 16 March 2018, ODTÜ Afet Merkezi, Ankara.

Açıkalın, O. (2017a). Yüzyılın Hesabı: Deprem Bağlamında Dirayetli Toplumun Neresindeyiz? İstanbul: Yeni İnsan Yayınevi.

Açıkalın, O. (2017b). Civil Society and Disaster Resilience in Turkey (Un)Making Europe: Capitalism, Solidarities, Subjectivities, 13th Conference of the European Sociological Association, Atina - Yunanistan, 29 August - 1 September. www.esa13thconference.eu.

Açıkalın, O. (2017c). Earthquakes and Society: Rethinking and Rebuilding Our Relations with Knowledge. Advances in Social Sciences Research Journal, 4(25): 146-156.

AFAD. (2018). Türkiye Deprem Tehlike Haritası. https://www.afad.gov.tr/tr/24212/TurkiyeDeprem-Tehlike-Haritasi

AFAD. (2014). Müdahale, lyileştirme ve Sosyoekonomik Açıdan 2011 Van Depremleri. Ankara: AFAD.

Buluş Kırıkkaya, E., ve Gerdan, S. (2018). Engelli ve Engelli Adayı Bireylerin Bir Afet Anında Nasıl Davranacaklarına İlişkin Görüşleri. Resilience (Dirençlilik), 2(2), 123-129.

Creswell, J. W. (2016), Nitel Araştırma Yöntemleri: Beş Yaklaşıma Göre Nitel Araştırma Deseni, Ankara: Siyasal Kitabevi.

Eliöz, M., Zeki Demir, A., Akbuğa, E. (2017). Engelli Dostu İller Sıralaması Çalışması. Akademik Sosyal Araştırmalar Dergisi, 50, 348-365.

Ergünay, O. (2008). Afet Yönetiminde Kurumsal Yapılanma ve Mevzuat Nedir? Nasıl Olmalıdır? Istanbul Depremini Beklerken Sorunlar ve Çözümler, Bildiriler Kitabı, ss.97-108. 20 Eylül 2008 CHP İstanbul Deprem Sempozyumu.

Gökçen, O., Özden, Ş., ve Demir, A. (2008). Türkiye'de Afetlerin Mekansal ve İstatistiksel Dağııımı Afet Bilgileri Envanteri. Ankara: AFAD.

Kıran, İ. ve Rashem, K. (2007). Zihinsel Engelli Çocuk Annelerine Eğitsel ve Psikolojik Destek. Büyüteç, 1, 28-29.

Neuman, W, L. (2014). Toplumsal Araştırma Yöntemleri Nitel ve Nicel Yaklaşımlar, Cilt I, II, Ankara: Yayın Odası Yayıncılık.

Okay, N., İlkkaracan İ. (2018). Toplumsal Cinsiyete Duyarlı Afet Risk Yönetimi. Resilience (Dirençlilik), 2(1), 1-12.

Özceylan, D., Coşkun, E. (2012a). Türkiye'deki İllerin Sosyo- Ekonomik Gelişmişlik Düzeyleri ve Afetlerden Sosyal ve Ekonomik Zarar Görebilirlikleri Arasındaki İlişki. İstanbul Üniversitesi Işletme Fakültesi Dergisi, 41(1), 31-46. 
Özceylan, D., Coşkun, E. (2012b). Van Depremleri Sonrası Yaşananlar Işığında Sosyal ve Ekonomik Zarar Görebilirlik Çalışmalarının Önemi. Eskişehir Osmangazi Üniversitesi Dergisi, 7(1), 167-186.

PreventionWeb. (2019). Opinion: Disaster Displacement is a 21st Century Challenge. www.preventionweb.net, May 14, 2019.

Saygılı, S. (2011). Yaşlı Kimdir? Somuncu Baba Dergisi, 134, 67-68.

Sendai Afet Risk Azaltımı Çerçevesi (SFDR). (2015). Sendai Afet Risk Azaltımı Çerçevesi Raporu 2015-2030. http://www.preventionweb.net/files/43291 sendaiframeworkfordrren.pdf

Varol, N., Gültekin, T. (2016). Afet Antropolojisi. Elektronik Sosyal Bilimler Dergisi, 15(59), 1431-1436. 